九病虫研会報 $35 ： 157-159$ (1989)

Proc. Assoc. Pl. Prot. Kyushu $35 ： 157-159$ (1989)

\title{
カンザワハダニに詨する合成ピレスロイド系 殺虫剂の影響
}

\author{
坂本 孝義1) -上村 親士2! \\ (熊本県茶業試験場)
}

Toxicity of Synthetic Pyrethroids to Kanzawa Spider Mite. Takayoshi SAKAмото and Chikashi Kamimura (Kumamoto Tea Experiment Station, Kumamoto, Kumamoto 862)

近年, チャの害虫を対象とする合成ピレスロイド系殺 虫唷（以下合ピレ堉）が次々と登録されている。合ピレ 棛はチャノコカクモンハマキ, チャノキイロアザミウマ, チャノミドリヒメヨコバイ等の害虫に対して効果が高く, 長い残効性を示し，有機リン剤に抵抗性となった害虫に 対しても有効であるなど，長所も多い。

しかし合ピレ剂を散布した場合，散布後にカンザワハ ダニ Tetranychus kanzawai KISHIDA の密度が異常に高くな る異常增殖現象（リサージェンス）が起こり，有効な殺 ダニ率が限られている現況においては極めて使用しにく い薬䍑となっている。

リサージェンス回避対策としては，なるべくハダ二類 に対して活性が高い薬骩を使用するという考えがある。 しかし，カンザワハダニに対する合ピレ䍑の影響につい ていまだ十分に検討されておらず，リサージェンスの起 こるメカニズムも明らかにされていない。

そこで著者らは，カンザワハダニ成虫および卵に対す る合ピレ剤の影響について若干の試験を行ったので,こ こに報告する。本稿をまとめるにあたって御助言をいた だいた熊本県果樹試験場行徳裕技師に深謝する。

\section{材料及び方法}

カンザワハダニは静岡県金谷町の茶園より採集した個 体を実験宝においてチャ葉およびインゲン葉で增殖した ものを供試し、リーフディスク法で試験した。

\section{a 殺卵活性試験}

リーフディスクに雌成虫を接種し, 裴日雌成虫を除去, 接種 2 日後に供試薬㘊に10秒間浸漬した。風乾後に供試 卵を計数し，処理10日後にふ化状況を調查した。供試卵 数は一濃度当たりおおむね100個であった。

\footnotetext{
1) 現在 熊本県芦北農業改良普及所

2) 現在 熊本県食品加工研究所
}

\section{b 殺成虫活性試験}

リーフディスクに雌成虫を 5 頭/葉接種し, 翌日不健 全個体を除去, 供試薬骩に10秒間浸漬した。処理 2 日後 に生死蜘及び水死虫数を調查した。結果はアボットの 補正を行い，プロビット法によって LC等を求めた。

供試薬郕は，殺卵活性試験ではフルバリネート20\%水

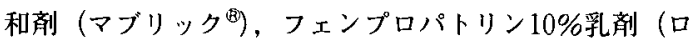
ディー可)，ビフェントリン $2 \%$ 水和剤(テルスター旬) の3薬郕, 殺成虫活性試験ではこれにフルシトリネート $5 \%$ 水和片 (ペイオプ) を加えた 4 楽唷で行った。

なお，浸漬等の作業は室温で行ったが，飼育は $25^{\circ} \mathrm{C} の$ 恒温条件下で行った。

\section{結 果と考 察}

\section{a 殺畉活性試験}

補正末ふ化卵率はフルパリネート水和剤 $100 \mathrm{ppm}$ 1.9\%,フェンプロパトリン乳剤 $100 \mathrm{ppm}$ で $0 \%$, ビフ エントリン水和郕 $20 \mathrm{ppm}$ で11.4\%といずれの供試薬剤 も実用濃度で50\%に達せず，卵に対する効果は極めて低 かった (第 1 表)。これは合ピレ剤が卵殻に浸透しない ためと考えられる。

しかし，処理卵からふ化した個体はいずれの供試薬剤 でも死亡虫率が高く, 補正死虫率はフルバリネート水和

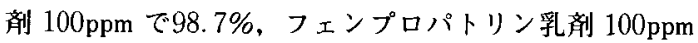
で $82.5 \%$, ビフェントリン水和敵 $20 \mathrm{ppm}$ で $100 \%$ といず れの供試薬唷も実用濃度で $80 \%$ を越えていた。これはふ 化時に卵㪍表面に付着した薬郕, あるいはふ化直後に葉 表面の薬戍に接種して死亡したものと考えられる。この ように initial kill 効果が高いことはミカン八ダニにつ いても知られている（行德ら，1988）。

b 殺成虫活性試験

各薬骩各濃度における死亡虫率をアボットの補正式で 補正し，プロビット計算した結果，第 2 表に示すような 
第 1 表 カンザワハダニ卵の合成ピレスロイド剤に対する感受性

\begin{tabular}{|c|c|c|c|c|c|c|c|}
\hline 薬 & 剂 & 名 & 濃 度 (ppm) & 末 s 化 邲*) & 死亡幼虫 ${ }^{*)}$ & 水死幼虫 ${ }^{*)}$ & 生存幼虫* \\
\hline \multirow[t]{3}{*}{ フルハリ } & ネー & 和郕 & 200 & 14.0 & 61.2 & 24.8 & 0 \\
\hline & & & 100 & 6.1 & 58.8 & 34.3 & 0.8 \\
\hline & & & 50 & 4.5 & 68.8 & 24.8 & 1.9 \\
\hline 無 & 処 & 理 & - & 4.3 & 0 & 4.2 & 91.5 \\
\hline \multirow[t]{3}{*}{ フェンプ } & コパト & 乳戍 & 200 & 23.4 & 64.3 & 9.7 & 2.6 \\
\hline & & & 100 & 2.6 & 55.6 & 30.5 & 11.3 \\
\hline & & & 50 & 3.3 & 29.8 & 32.2 & 34.7 \\
\hline 無 & 処 & 理 & - & 6.6 & 0.7 & 2.2 & 90.5 \\
\hline \multirow[t]{3}{*}{ ビフェン } & トリ & 和郕 & 40 & 16.6 & 61.8 & 21.6 & 0 \\
\hline & & & 20 & 15.7 & 60.9 & 23.4 & 0 \\
\hline & & & 10 & 8.6 & 71.2 & 20.2 & 0 \\
\hline 無 & 処 & 理 & - & 4.8 & 3.8 & 1.5 & 89.9 \\
\hline
\end{tabular}

*）供試卵数に対する百分率

第2表 カンザワハダニ成虫の合成ピレスロイド郕に対する感受性

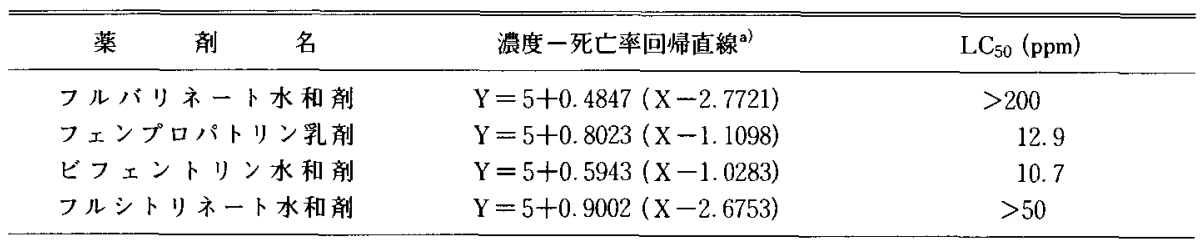

a) $\mathrm{X}$ : 漂度 $(\mathrm{ppm}) \mathrm{Y}:$ プロピット

第 3 表 カンザワハダ二成虫の合成ピレスロイド剤に対する忌避活性

\begin{tabular}{|c|c|c|c|}
\hline 剂 & 濃度一忌避率回帰直線 ${ }^{a)}$ & run-off $f_{50}(\mathrm{ppm})$ & 活性指標 b) \\
\hline フルバリネート水和剂 & $\mathrm{Y}=5+0.4847(\mathrm{X}-1.9019)$ & 79.8 & 7.4 \\
\hline フェンプロパトリン乳㓲 & $\mathrm{Y}=5+0.8011(\mathrm{X}-1.0499)$ & 11.2 & 1.2 \\
\hline ビフェントリン水和㓲 & $Y=5+0.7780(X-1.0760)$ & 11.9 & 0.9 \\
\hline フルシトリネート水和剤 & $\mathrm{Y}=5+0.8257(\mathrm{X}-2.8126)$ & $>50$ & 0.7 \\
\hline
\end{tabular}

a) $\mathrm{X}:$ 濃度 $(\mathrm{ppm}) \quad \mathrm{Y}:$ プロピット b) $\mathrm{LC}_{50} / \mathrm{run}^{-o f f_{50}}$

第 4 表 カンザワハダニ成虫の合成ピレスロイド剤に対する感受性及び忌避活性

\begin{tabular}{|c|c|c|c|}
\hline 薬 & 名 & 濃度一 (死亡十忌避) 率回㷌直線 ${ }^{\mathrm{A}}$ & $50 \%$ (死亡十忌避) 濃度 \\
\hline \multicolumn{2}{|c|}{ ブルバリネ一ト水和戍 } & $\mathrm{Y}=5+0.7291(\mathrm{X}-1.6088)$ & $40.6 \mathrm{ppm}$ \\
\hline \multicolumn{2}{|c|}{ フェンプロパリン乳剤 } & $\mathrm{Y}=5+0.7043(\mathrm{X}-0.4994)$ & 3.2 \\
\hline \multicolumn{2}{|c|}{ ビフェントリン水和凬 } & $Y=5+0.7058(X-0.2559)$ & 1.8 \\
\hline \multicolumn{2}{|c|}{ フルシトリネート水和剤 } & $Y=5+0.7546(X-2.2377)$ & $>50$ \\
\hline
\end{tabular}

a) $\mathrm{X}$ : 濃度 $(\mathrm{ppm}) \quad \mathrm{Y}:$ プロピット

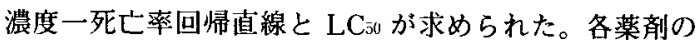
LC50を比較すると薬脷によって活性の差が認められ, ビフェントリン水和威ニフェンプロパトリン乳戍 $>フ ル$ シトリネート水和戍>フルバリネート水和剤の順であっ た。フェンプロパトリン乳剂は LC 50 が実用濃度の $1 / 8$ 程度であり殺ダニ効果が期待できるが，ビフェントリン 水和䨩は実用濃度の $1 / 2$ 程度であり，若干の密度抑制効
果はあるものの不十分と考えられる。他の供試薬剤では 殺ダ二効果が期待できなかった。

ここで，水死虫は被散布個体が散布葉外に忌避（逃 避）した結果水死したと考えられるので，プロビット法 によって50\%忌避摆度 (run-off50, PENMAN et al. 1986) を求めた（第 3 表）。

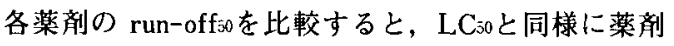


によって活性の差が認められた。活性はフェンプロパト リン乳剤 =ビフェントリン水和剤>フルバリネート水和 䋭>フルシトリネート水和郕の順であった。

LC50と run-off 50 比較した場合，ビフェントリン水 和剤とフェンプロパトリン乳剤ではほぼ同等, フルバリ ネート水和剤では $\mathrm{LC}_{50}>$ run-off 50 であり, フルシトリ ネート水和剂ではLC50< run-off50であった。

また，PENMAN et al（1986）が提唱した活性指標 (L.C50/run-off 50 ) を求めると,フルバリネート水和剂は 7.4であったが，他の供試薬剤は0.7〜1.2てあった。こ のことから，フルバリネート水和剤は合ピレ剤の中でも カンザワハダニに対する忌避効果が高い薬㓲といえる。

さらに，殺虫活性および忌避活性を総合して合ピレ剂 の効果と考え $50 \%$ 死亡及び忌避率を求めた（第 4 表）。 $50 \%$ 死亡および忌避濃度を比較すると, ビフェントリン 水和剤=フェンプロパトリン乳郕>フルパリネート水和 剤>フルシトリネート水和郕の順で活性の差が認められ, ビフェントリン水和剤が実用濃度の約 $1 / 10$, フェンプロ パトリン乳剂が同約 $1 / 33$ ，フルバリネート水和剂が同約 1/2であった。

このように合ピレ剤は薬剤によってカンザワハダニに 対する活性が異なるが，このことはナミハダニやリンゴ
ハダニ (IfTNER and Hall, 1983, PENMAN et al 1986), ミカンハダニ（行徳・磯田，1988）でも知られている。 この活性の差が散布後のカンザワハダニの密度回復ある いはりサージェンスの発現までの期間やその頻度に影響 してくるものと考えられる。

また, リサージェンスのメカニズムについて検討する 場合, カンザワハダニの産卵能力や生有速度, 更には合 ピレ剤の残効性についても考虑する必要がある。

本稿では宔内試験により合ピレ剤のカンザワハダ二成 虫及び卵に対する活性について報告したが，今後ほ場試 験を行い, 合ピレ剤の活性とリサージェンスとの関係に ついても改めて検討しなければならない。

\section{引用 文 献}

1) 行德 裕 - 磯田 阵晴 (1988) 第32回応動昆大会講演要旨 集 140. 2) 行徳 裕·磯田 隆晴 ·上村 道雄 (1988) 九州病虫研報34：184-186. 3) IFTNER, D. C. and HALL, F. R. (1983) J. Econ. Entomol. $76: 687-689$. 4) PENMAN, D. R., Chapman, R. B. and Bowie, M. H. (1986) J. Econ. Entomol. $79: 1183-1187$.

(1989年 4 月21日＼cjkstart受領) 